\title{
Health Risk Surveillance of Arsenic in Wastewater, Groundwater, and Agricultural Land along Hudaira Drain, Pakistan Using GIS Techniques
}

\author{
Ambreena Javaid ${ }^{1,2 *}$, Sajid Rashid Ahmad², Abdul Qadir ${ }^{2}$ \\ ${ }^{1}$ Kinnaird College for Women, Lahore, Pakistan \\ ${ }^{2}$ College of Earth and Environmental Science, University of the Punjab, Lahore, Pakistan.
}

Received: 3 June 2017

Accepted: 7 December 2017

\begin{abstract}
The present study focuses on the health risk assessment and spatial distribution of arsenic in Hudaira Drain and its adjoining areas using GIS techniques. For this purpose, surface water, groundwater, and soil samples were collected from the nine transects across the drain. The results of the present study indicated that two of the examined transects were situated in a high arsenic concentration zone and this area was dominated by industrial activities. A strong correlation at 95\% confidence level exists among drain water, ground water, and soil. Furthermore, Hazard quotient (HQ) was calculated and results indicated that about $75 \%$ of children and $50 \%$ of adults may be affected by arsenic through drinking of groundwater. The presence of arsenic in groundwater, which is a major source of drinking water in this area, may cause excess lifetime cancer risk (ELCR) $>10^{-4}$ in $44.4 \%$ of the resident human population. There is an urgent need to focus on the arsenic contamination issue in this area in order to protect the groundwater, surface water, and soil resources from arsenic contamination for better human health.
\end{abstract}

Keywords: groundwater, hazard quotient, non-carcinogenic, excess lifetime cancer risk

\section{Introduction}

A major source of toxic elements is the industrial and municipal wastewater that contaminates soil and groundwater. These toxic metals (As, $\mathrm{Cd}, \mathrm{Cr}, \mathrm{Pb}, \mathrm{Hg}$, etc.) ultimately enter the human food chain mainly through drinking water and contaminated food [1].

*e-mail: ambreena.mubashir@gmail.com
The crops become polluted due to soil pollution, ultimately putting the adverse effects of metals on human food [2-4]. This intensity of adverse effects is aggravated if non-essential metals are consumed. The non-essential metals are responsible for mutagenesis and teratogenesis, and disrupt the metabolic integrity of the human body [5].

Arsenic is categorized as a non-essential metal found in low concentrations within the environment. Arsenic is present in the earth's crust and is exposed to biological 
systems through weathering, mining, and excavation [6]. The de-absorption of arsenic from hydroxides of manganese, iron, and aluminum; oxidation of arseniccarrying sulfides and reductive dissolution of arsenicbearing iron hydroxides are the major natural source of arsenic in drinking water [7,8]. In the environment, arsenic is activated due to the combination of various natural processes like weathering, biological measures, volcanic eruptions, and anthropogenic activities [9]. Arsenic combines with other elements and forms compounds of organic and inorganic arsenic. Inorganic arsenic is found in compounds with oxygen, sodium, potassium, copper, chlorine, iron, and sulphur. The organic form of arsenic is formed by the combination of carbon and hydrogen with arsenic in animals and plants. The food that carries organic arsenic is quickly absorbed into the body. Inorganic arsenic is more toxic and can have severe and chronic effects. It is accumulated in the body and becomes more poisonous due to continuous exposure. Arsenic is a carcinogen even at very low levels of exposure, with no possible useful metabolic functions for human beings $[10,11]$.

Exposure to arsenic-polluted drinking water causes skin, liver, kidney, and lung cancer [12]. Moreover, chronic intake of inorganic arsenic causes skin lesions, including changes in pigmentation - principally on the keratosis of the palm of hands, extremities, and trunk, and soles of feet [13-16]. At the end of the second millennium, in Asia only, water containing arsenic has affected more than 100 million people [17, 18]. Apart from anthropogenic sources, geopogenic sources are also one of the major reasons for the arsenic-affected human population $[19,20]$.

Quantitative risk and exposure analysis have the ability to determine the impartial view of the present status, if variables like chronic daily intake, intake factor, average body weight, time exposed, frequency, and duration for an entire lifetime are considered. The most affected countries by arsenic from groundwater resources are Bangladesh, Nepal, various Indian states, Pakistan, Cambodia, Myanmar, Vietnam, Lao People's Democratic Republic, China, and Vietnam [17, 21]. In Pakistan, China, and Cambodia, the risk levels have been calculated on the basis of drinking water polluted with arsenic in relevance to chronic exposure. After the arsenic disaster in Bangladesh and other neighboring countries, the government of Pakistan has initiated an assessment of drinking water with the help of UNICEF, which includes the development of various plans to determine and control the arsenic threat to drinking water [22].

A few studies on arsenic pollution in groundwater and its sources have been carried out in Pakistan [23-30]. Arsenic is a burning issue nowadays in Pakistan, but no comprehensive literature about arsenic contamination is available. However, some reports related to arsenic contamination have been documented from various parts of Pakistan. The present study has been carried out to highlight the spatial distribution of arsenic in drain water, groundwater, and soil in order to find its possible risk. This is a first-time effort to highlight arsenic in groundwater, soil, and drain water of Lahore with the help of GIS to identify the arsenic hotspots and sources of arsenic within the vicinity of Lahore.

\section{Materials and Methods}

\section{Study Area}

Hudaira Drain is a $98.6 \mathrm{~km}$-long trans-boundary drain that starts from Indian Punjab. It enters Pakistan

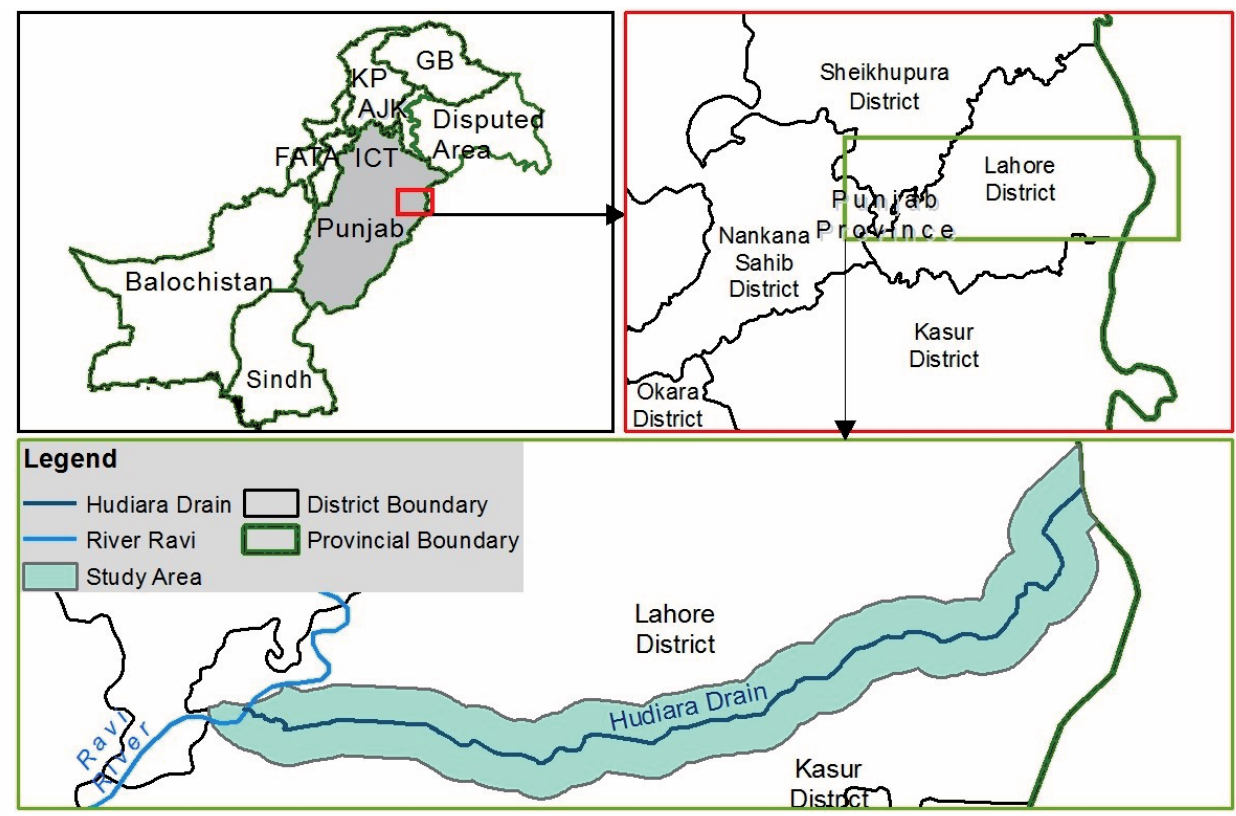

Fig. 1. Map of study area. 
Table 1. Sample summary.

\begin{tabular}{|c|c|c|c|c|}
\hline \multirow{2}{*}{$\begin{array}{l}\text { Sampling } \\
\text { Sites }\end{array}$} & \multirow{2}{*}{$\begin{array}{l}\text { Source of } \\
\text { Samples }\end{array}$} & \multicolumn{2}{|c|}{$\begin{array}{c}\text { Location } \\
\text { /Coordinates }\end{array}$} & \multirow[t]{2}{*}{ Soil type } \\
\hline & & $X$ & $\mathrm{Y}$ & \\
\hline \multirow{5}{*}{ Transect 1} & DW1, SD1 & 74.5940 & 31.4758 & Silt loam \\
\hline & GLP1 & 74.5896 & 31.4824 & \\
\hline & GRP1 & 74.5958 & 31.4700 & \\
\hline & GLE1, SBLE1 & 74.5789 & 31.4878 & Loam \\
\hline & GRE1, SBRE1 & 74.5978 & 31.4646 & Loam \\
\hline \multirow{5}{*}{ Transect 2} & DW2, SD2 & 74.5569 & 31.4441 & Silt loam \\
\hline & GLP2 & 74.5554 & 31.4492 & \\
\hline & GRP2 & 74.5555 & 31.4384 & \\
\hline & GLE2, SBLE2 & 74.5522 & 31.4529 & Loam \\
\hline & GRE2, SBRE2 & 74.5533 & 31.4334 & Silt loam \\
\hline \multirow{5}{*}{ Transect 3} & DW3, SD3 & 74.4988 & 31.4426 & Loam \\
\hline & GLP3 & 74.4973 & 31.4471 & \\
\hline & GRP3 & 74.4970 & 31.4376 & \\
\hline & GLE3, SBLE3 & 74.4934 & 31.4520 & Silt loam \\
\hline & GRE3, SBRE3 & 74.4948 & 31.4331 & Silt loam \\
\hline \multirow{5}{*}{ Transect 4} & DW4, SD4 & 74.4451 & 31.4216 & Silt loam \\
\hline & GLP4 & 74.4437 & 31.4261 & \\
\hline & GRP4 & 74.4434 & 31.4171 & \\
\hline & GLE4, SBLE4 & 74.4573 & 31.4366 & Loam \\
\hline & GRE4, SBRE4 & 74.4425 & 31.4104 & Loam \\
\hline \multirow{5}{*}{ Transect 5} & DW5, SD5 & 74.3925 & 31.3999 & Silt loam \\
\hline & GLP5 & 74.3908 & 31.4044 & \\
\hline & GRP5 & 74.3906 & 31.3954 & \\
\hline & GLE5, SBLE5 & 74.3860 & 31.4087 & Loam \\
\hline & GRE5, SBRE5 & 74.3878 & 31.3908 & Silt loam \\
\hline
\end{tabular}

near the village of Lallo after traversing $44.2 \mathrm{~km}$ through India and falls into the Ravi River in Pakistan [31]. The location of the drain in Pakistan is 31.4 $\left(31^{\circ} 23^{\prime} 42^{\prime \prime} \mathrm{N}\right)$ latitude and $74.13\left(74^{\circ} 8^{\prime} 1^{\prime \prime} \mathrm{E}\right)$ longitude (Fig. 1). In this region, a chain of aquifers is found which are limited in number. Most of these aquifers are not in geologic contact with surficial aquifers [32]. These aquifers are unconfined in nature [33]. This area receives an average $650 \mathrm{~mm}$ rainfall; out of $650 \mathrm{~mm}$, $65 \%$ rain falls during the southwestern monsoon (June to September) and $20 \%$ of rain falls during the northeastern monsoon. The remaining $15 \%$ of rain falls during winter. The drain flows over alluvial deposits of the Ravi. Due to the discharge of untreated industrial effluents and sewage, this rainstorm water stream is converted into a polluted wastewater drain [34-37]. Untreated industrial effluents of roughly

\begin{tabular}{|c|c|c|c|c|}
\hline \multirow{5}{*}{ Transect 6} & DW6, SD6 & 74.3335 & 31.3905 & Silt loam \\
\hline & GLP6 & 74.3524 & 31.3950 & \\
\hline & GRP6 & 74.3315 & 31.3862 & \\
\hline & GLE6, SBLE6 & 74.3268 & 31.4005 & Silt loam \\
\hline & GRE6, SBRE6 & 74.3495 & 31.3791 & Silt loam \\
\hline \multirow{5}{*}{ Transect 7} & DW7, SD7 & 74.2803 & 31.3790 & Silt loam \\
\hline & GLP7 & 74.2793 & 31.3846 & \\
\hline & GRP7 & 74.2778 & 31.3751 & \\
\hline & GLE7, SBLE7 & 74.2717 & 31.3912 & Silt loam \\
\hline & GRE7, SBRE7 & 74.2738 & 31.3719 & Silt loam \\
\hline \multirow{5}{*}{ Transect 8} & DW8, SD8 & 74.2235 & 31.3933 & Loam \\
\hline & GLP8 & 74.2222 & 31.3991 & \\
\hline & GRP8 & 74.2207 & 31.3894 & \\
\hline & GLE8, SBLE8 & 74.2328 & 31.3989 & Loam \\
\hline & GRE8, SBRE8 & 74.2160 & 31.3865 & Silt loam \\
\hline \multirow{5}{*}{ Transect 9} & DW9, SD9 & 74.1622 & 31.4000 & Loam \\
\hline & GLP9 & 74.1605 & 31.4044 & \\
\hline & GRP9 & 74.1593 & 31.3951 & \\
\hline & GLE9, SBLE9 & 74.1518 & 31.4075 & Loam \\
\hline & GRE9, SBRE9 & 74.1542 & 31.3895 & Silt loam \\
\hline
\end{tabular}

Where:

DW $=$ Drain water samples

$\mathrm{GRP}=$ Groundwater samples on right side of drain at half $\mathrm{km}$ $\mathrm{GLP}=$ Groundwater samples on left side of drain at half $\mathrm{km}$ $\mathrm{GRE}=$ Groundwater samples on right side of drain at one $\mathrm{km}$ $\mathrm{GLE}=$ Groundwater samples on left side of drain at one $\mathrm{km}$ $\mathrm{SD}=$ Soil samples on drain

SBRE $=$ Soil samples on right side of drain at one $\mathrm{km}$ SBLE $=$ Soil samples on left side of drain at one

120 different industries are discharged in this drain. 178 cusecs $/ 5.04 \mathrm{~m}^{3}$ per second of untreated industrial effluent and sewage waste are discharged annually in this drain [38]. There are four tributaries of Hudaira Drain: Minhala Drain, Charrar Drain, Ferozepur Road Drain, and Sattu Katla Drain. Sattu Katla is the largest tributary of Hudaira Drain of the above four. There are two other drains discharging into Sattu Katla: the Link Sattu Katla Drain and College Road Drain [39].

\section{Field Survey}

An exclusive field survey was conducted for the sampling of drain water, groundwater, and soil from 31 March to 11 April 2015 (pre-monsoon), followed by another survey commencing from 23 to 31 October 2015 (post-monsoon) for drain water and groundwater only. Pre-monsoon and post-monsoon values were 
analyzed to get the mean value used in this study. Soil samples were not collected again in post monsoon season because the properties of soil do not change so frequently. These samples were tested and then mapped through different GIS techniques. Finally, the results were analyzed to assess the spatial concentration of arsenic level in the study area. The arsenic standard units for drain water, groundwater, and soil are $1000 \mathrm{ppb}$ or $\mu \mathrm{g} / \mathrm{L}$ (NEQS), 10ppb or $\mu \mathrm{g} / \mathrm{L}$ (WHO), and should not exceed $3.9 \mathrm{mg} / \mathrm{kg}$ (FAO).

\section{Sampling Techniques}

The decision of sampling sites was carried out on the basis of heterogeneity of anthropogenic and natural factors. In this regard, a comprehensive preliminary survey was conducted, and information related to the study area was also collected. Discussions related to properties of soil and water with different experts like environmentalists, government, and non-government concerned persons led to the decision for buffer zones and sample intervals. The locations of the samples were

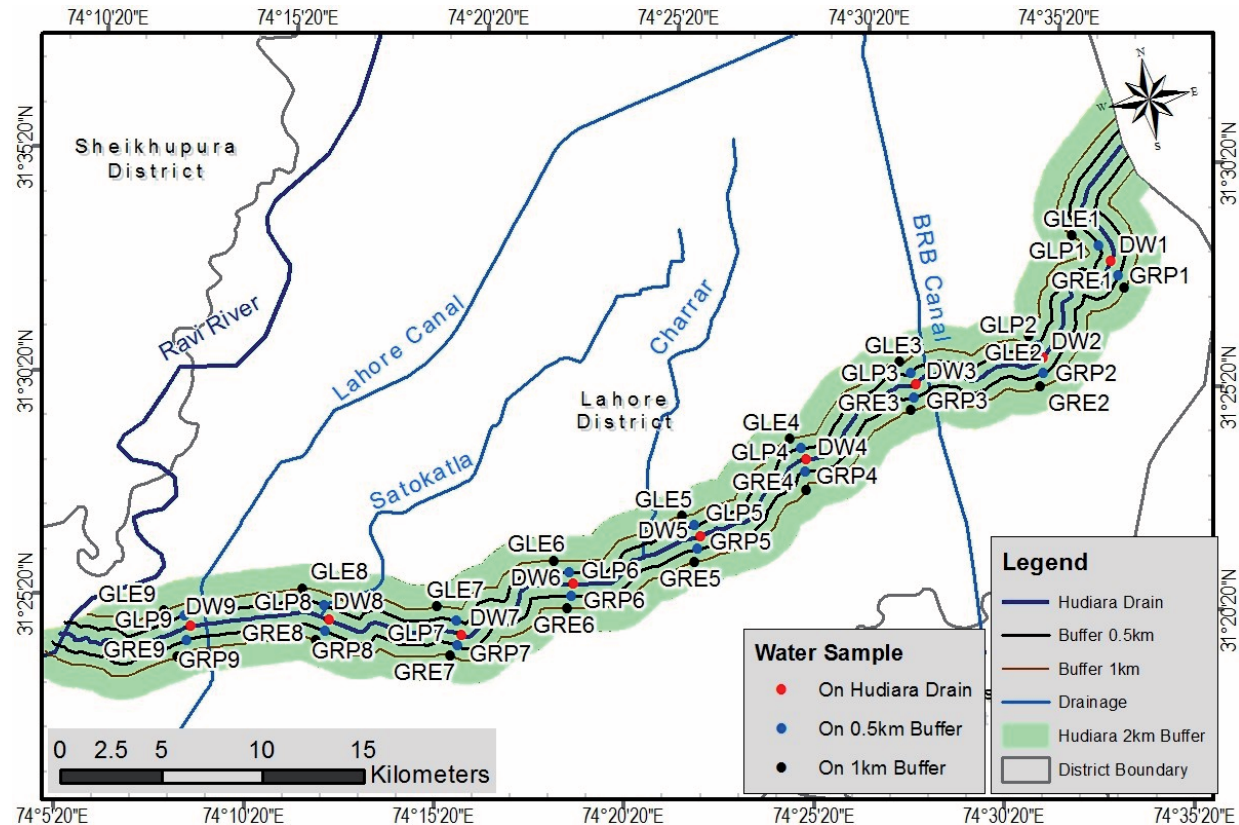

Fig. 2. Sample sites for drain water and groundwater.

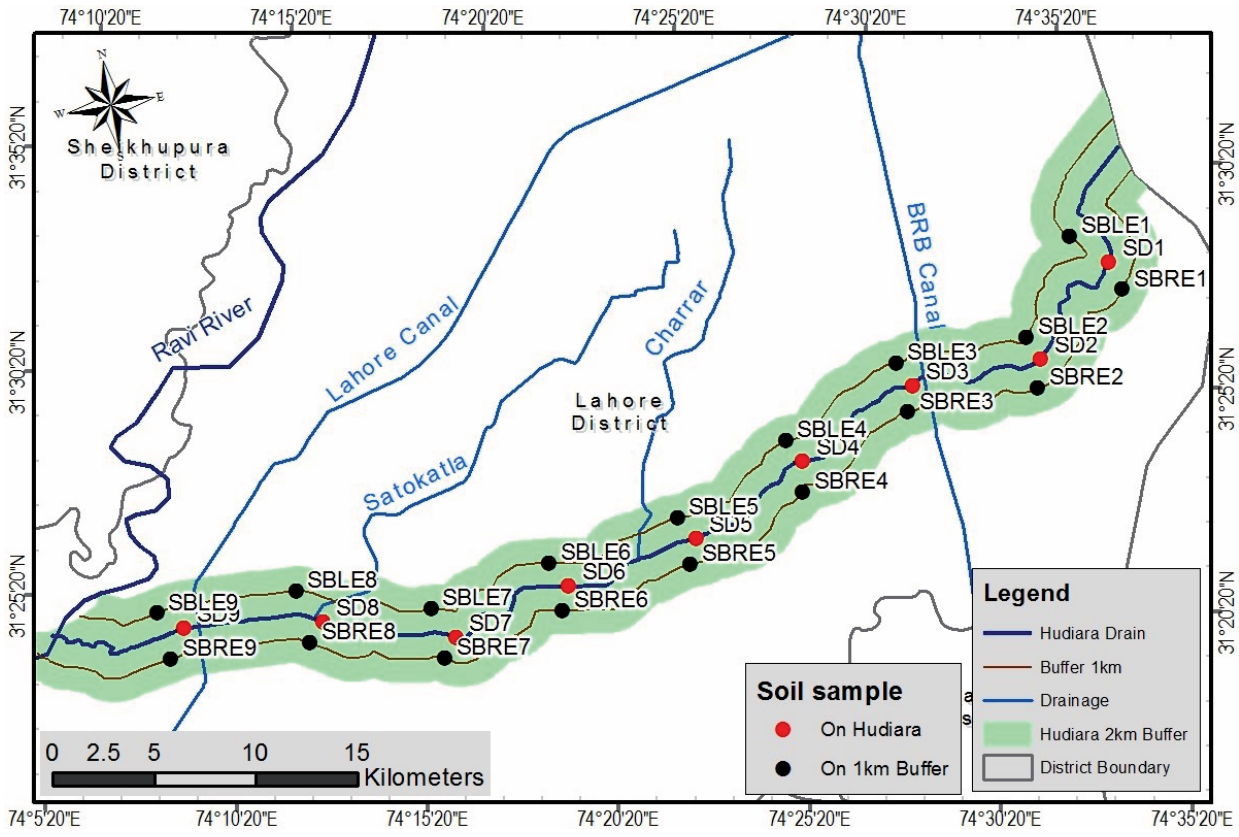

Fig. 3. Sample sites for soil. 
identified or traced with the help of GARMIN eTrex 30 GPS. A systematic sampling technique was used to mark the sampling sites (Table 1). Two buffer zones were selected at $0.5 \mathrm{~km}$ and $1 \mathrm{~km}$ on both sides from the main Hudaira Drain. Samples from the drain were taken every $3 \mathrm{~km}$. 20 drain water samples were collected from the main Hudaira Drain through grab sampling procedure.

Water samples were taken from $0.5 \mathrm{~km}$ buffer zone and $1 \mathrm{~km}$ buffer zone on both sides of the main Hudaira drain at a distance of $6 \mathrm{~km}$ along the drain. A total of 36 water samples were collected from both sides of the drain. For the collection of tap water, the mouth of the tap was heated for 1-2 minutes and then water was allowed to run for 5 minutes. For microbiological analysis, plastic bottles of $200 \mathrm{ml}$ capacity were used to collect the samples of water. In the microbiological analysis, only the absence or presence of E. Coli was checked. These samples were kept in an icebox and brought to the laboratory within the recommended time period. Tap water was also collected in $0.5 \mathrm{~L}$ plastic sampling bottles. Proper code numbers were labeled on all bottles before analysis in the laboratory. Samples were immediately preserved by adding $2 \mathrm{ml} / \mathrm{L}$ concentrated nitric acid $\left(\mathrm{HNO}_{3}\right)$ as per APHA-AWWA-WEF [40]. Different analyses were conducted on the samples in 2015.

Soil sampling was carried out at a distance of one $\mathrm{km}$ buffer zone on both sides of the drain and along the drain. The consecutive interval between the soil samples was $6 \mathrm{~km}$. 27 soil samples were collected: 9 along the drain and 18 from the one $\mathrm{km}$ buffer on both sides of the drain. The auger method was used for soil sampling at one $\mathrm{km}$ buffer zone. The auger method along with composite soil sampling method was done to get the soil samples alongside the drain. For the purpose of analysis, samples were kept in airtight polythene bags. Each sample bag was labeled carefully according to the sample code. Each polythene bag contained about 1.5 kilograms of soil. Before chemical and physical analysis, soil samples were sieved through a $2 \mathrm{~mm}$ sieve. These sieved samples were later kept in polythene bags for various chemical and physical analyses.

Thirty-six groundwater samples were selected for arsenic testing from $0.5 \mathrm{~km}$ and $1 \mathrm{~km}$ buffer on both sides of the drain, 9 drain samples were selected from the main drain and 27 soil samples were selected from along the Hudaira Drain and $1 \mathrm{~km}$ buffer from the drain on the basis of systematic random sampling, as shown in Figs 2 and 3. Arsenic samples were analyzed through atomic absorption spectrometry (AAS). Finally, statistical analysis, which includes descriptive statistics, scatter plots, and box plots was done using STATISTICA 10 software.

For a non-carcinogenic approach, the chronic daily intakes (CDI) for adults and children were calculated using Equations I and II:

$$
\begin{gathered}
\mathrm{CDI}_{\text {water-nc-ing }}=\left[\mathrm{C}_{\mathrm{g} \text {-water }} \times \mathrm{EF}_{\text {resw }} \times \mathrm{ED}_{\text {resw }} \times \mathrm{IRW}_{\text {resw }}\right] \\
\div\left[365 \times \mathrm{ED}_{\text {resw }} \times \mathrm{BW}_{\text {reswa }}\right] \text { For Adults }
\end{gathered}
$$

$$
\begin{gathered}
\mathrm{CDI}_{\text {water-nc-ing }}=\left[\mathrm{C}_{\mathrm{g} \text {-water }} \times \mathrm{EF}_{\text {reswc }} \times \mathrm{ED}_{\text {reswc }} \times \mathrm{IRW}_{\text {reswc }}\right] \\
\quad \leftarrow\left[365 \times \mathrm{ED}_{\text {reswc }} \times \mathrm{BW}_{\text {reswc }}\right] \text { For Children }
\end{gathered}
$$

For carcinogenic cases, equations III and IV were used to compute the age-adjusted CDI

$$
\mathrm{CDI}_{\text {water - ca-ing }}=\left[\mathrm{C}_{\mathrm{g} \text { - water }} \times \mathrm{IFW}_{\text {resw - adj }}\right] / \mathrm{AT}_{\text {reswc }}
$$

... where:

$$
\begin{aligned}
& \left.\mathrm{IFW}_{\text {resw - adj }}=\left[\mathrm{ED}_{\text {reswc }} \times \mathrm{EF}_{\text {reswc }} \times \mathrm{IRW}_{\text {reswc }}\right] / \mathrm{BW}_{\text {reswc }}\right] \\
& +\left[\left[\mathrm{ED}_{\text {resw }}-\mathrm{ED}_{\text {reswc }}\right] \times \mathrm{IRW}_{\text {reswa }}\right] / \mathrm{BW}_{\text {reswa }}
\end{aligned}
$$

Excess lifetime cancer risk (ELCR) and the significant hazard quotient (HQ) were calculated using equations $\mathrm{V}$ and VI, respectively:

$$
\begin{gathered}
\mathrm{ELCR}=\mathrm{CDI}_{\text {water }-\mathrm{ca}-\text { ing }} \mathrm{XS \textrm {SF } _ { \text { oral } }} \\
\mathrm{HQ}=\mathrm{CDI}_{\text {water }-\mathrm{nc}-\mathrm{ing}} / \mathrm{RfD}
\end{gathered}
$$

Table 2 shows the input variables for exposure assessment, risk, and hazard analysis.

\section{Spatial Generalization of Samples through GIS}

In the initial phase, groundwater, soil, and drain water parameters (location/sampling sites and arsenic concentration) were entered in MS Excel database format because Excel can be easily transported to the GIS database for further analysis. A shape file of the sampling location was prepared by importing the database file prepared in Excel. Once the data were imported as a point layer, spatial distribution maps of the attribute information were created using spatial interpolation techniques (IDW). Interpolation is a method of converting point data to surface data. Interpolation is the process used to calculate the values of locations that do not have sample points. It is based on the rule of spatial autocorrelation in which measurement is done on the degree of relationship between near and far-away objects, i.e., where data are not known, the interpolation method is used.

In this research we used the inverse distance weighted (IDW) interpolation method to produce distribution maps on a spatial basis for different parameters. IDW interpolation implements the assumption that things that are close to one another are more alike than those that are farther apart. In this study, arsenic concentration in groundwater, drain water, and soil was categorized as low, moderate, and high in order to identify the hotspot areas. The soil values range between 15.89-39.14 $\mu \mathrm{g} / \mathrm{L}$ (0.0391-0.0159 mg/kg) and were within the FAO limits. The hotspot areas identified were based on the obtained data to estimate the future scenario. Soil values were categorized into a relative low group (15-22 $\mu \mathrm{g} / \mathrm{L})$, moderate group (23-31 $\mu \mathrm{g} / \mathrm{L}$ ), and high group (above $31 \mu \mathrm{g} / \mathrm{L}$ ). For drain water, the values ranged from 4.36 to $22.40 \mathrm{ppb}$ and were within the NEQS standards, whereas for groundwater the values ranged from 2.75 to 
Table 2. Input Parameters for CDI, ELCR, and HQ [46].

\begin{tabular}{|c|c|c|c|}
\hline Parameter & Abbreviation & Unit & Value \\
\hline Chronic daily intake (water-non-carcinogenic-ingestion) & $\mathrm{CDI}{ }_{\text {water-nc-ing }}$ & $\mathrm{mg} / \mathrm{kg}$-day & \\
\hline Concentration & $\mathrm{C}_{\mathrm{g} \text {-water }}$ & $\mathrm{mg} / \mathrm{L}$ & \\
\hline Adjusted intake factor & IFW $_{\text {resw-adj }}$ & $\mathrm{L} / \mathrm{kg}$ & 380 \\
\hline Average time- noncarcinogenic & $\mathrm{A}_{\text {Tresw }}$ & Day & 10950 \\
\hline Exposure duration - adult & $\mathrm{ED}_{\text {reswa }}$ & Year & 30 \\
\hline Exposure frequency - child & $\mathrm{EF}_{\text {reswc }}$ & day/year & 350 \\
\hline Water intake rate - child & IRW $_{\text {reswc }}$ & L/day & 1 \\
\hline Body weight - child & $\mathrm{BW}_{\text {reswe }}$ & $\mathrm{Kg}$ & 15 \\
\hline Exposure duration - resident & $\mathrm{ED}_{\text {resw }}$ & Year & 30 \\
\hline Exposure duration - child & $\mathrm{ED}_{\text {reswc }}$ & Year & 6 \\
\hline Exposure frequency & $\mathrm{EF}_{\text {reswa }}$ & Day/year & 350 \\
\hline Water intake rate - adult & $\mathrm{IRW}_{\text {reswa }}$ & L/day & 2 \\
\hline Body weight - adult & $\mathrm{BW}_{\text {reswa }}$ & $\mathrm{Kg}$ & 70 \\
\hline Average time- carcinogenic & $\mathrm{AT}_{\text {reswc }}$ & Day & 25550 \\
\hline Chronic daily intake (water-carcinogenic-ingestion) & $\mathrm{CDI}_{\text {water-ca-ing }}$ & $\mathrm{mg} / \mathrm{kg}$-day & \\
\hline Oral slope factor & $\mathrm{SF}_{\text {oral }}$ & (mg/kg-day)-1 & 1.5 \\
\hline Reference dose & $\mathrm{R}_{\mathrm{Fd}}$ & $\mathrm{mg} / \mathrm{kg}$-day & $3.00 \mathrm{E}-04$ \\
\hline
\end{tabular}

$22.35 \mu \mathrm{g} / \mathrm{L}$ and some were higher than WHO standards. For the study, drain water and groundwater were categorized as low group (up to $10 \mu \mathrm{g} / \mathrm{L}$ ), moderate group (11-18 $\mu \mathrm{g} / \mathrm{L}$ ), and high group (above $18 \mu \mathrm{g} / \mathrm{L}$ ).

\section{Results and Discussion}

Total arsenic concentrations in soil, drain water, and groundwater from different sites were analyzed. The descriptive statistics for arsenic results are shown in Table 3. Through IDW interpolation technique, it was observed that transects $1,2,3$ and 9 belong to low arsenic group as shown in Fig. 4. Along the drain, the mean value of arsenic for soil ranges from 21.61 to $29.27 \mu \mathrm{g} / \mathrm{L}(0.02161$ to $0.02927 \mathrm{mg} / \mathrm{kg})$ and along the

Table 3. Descriptive statistics for arsenic.

\begin{tabular}{|c|c|c|c|}
\hline $\begin{array}{c}\text { Descriptive } \\
\text { statistics }\end{array}$ & Drainwater & Groundwater & Soil \\
\hline Mean & 13.36 & 10.75 & 25.00 \\
\hline Median & 16.89 & 10.75 & 23.43 \\
\hline Std. Deviation & 7.07 & 5.94 & 5.94 \\
\hline Range & 18.04 & 19.60 & 23.3 \\
\hline Minimum & 4.36 & 2.75 & 15.9 \\
\hline Maximum & 22.40 & 22.35 & 39.1 \\
\hline
\end{tabular}

one $\mathrm{km}$ buffer the mean arsenic value ranges from 15.89 to $21.56 \mu \mathrm{g} / \mathrm{L}(0.01589$ to $0.02156 \mathrm{mg} / \mathrm{kg})$. For drain water and groundwater, transects 1,2 , and 3 belong to the low arsenic group (Fig. 5). In drain water, the mean arsenic value ranged from 4.36 to $5.35 \mu \mathrm{g} / \mathrm{L}$ and for groundwater it ranged from 2.75 to $5.33 \mu \mathrm{g} / \mathrm{L}$. These were the sites surrounding the area from where the drain enters Pakistan from India. Most of this area is comprised of agricultural land with scattered settlements.

Transects 4,5 , and 8 belong to the moderate arsenic group (Fig. 4). Along the drain, the mean value of arsenic for soil ranged from 28.53 to $29.77 \mu \mathrm{g} / \mathrm{L}(0.02853$ to $0.02977 \mathrm{mg} / \mathrm{kg}$ ) and along the one $\mathrm{km}$ buffer the mean arsenic value ranged from 21.29 to $25.72 \mu \mathrm{g} / \mathrm{L}(0.02129$ to $0.02572 \mathrm{mg} / \mathrm{kg}$ ). For drain water and groundwater, transects 4, 5, 8, and 9 belong to the moderate arsenic group (Fig. 5). In drain water the mean arsenic value ranged from 11.32 to $17.65 \mu \mathrm{g} / \mathrm{L}$ and for groundwater it ranged from 6.25 to $17.85 \mu \mathrm{g} / \mathrm{L}$. These were the sites that have agriculture on one side and industries on the other. Industries found in this group were mostly comprised of textiles (yarn and garments), food, and a few related to chemicals.

Transects 6 and 7 belong to high arsenic group (Fig. 4). Along the drain, the mean value of arsenic for soil ranged from 36.41 to $39.14 \mu \mathrm{g} / \mathrm{L} \quad(0.03614$ to $0.03914 \mathrm{mg} / \mathrm{kg}$ ) and along the one $\mathrm{km}$ buffer the mean arsenic value ranged from 28.46 to $31.82 \mu \mathrm{g} / \mathrm{L}(0.02846$ to $0.03182 \mathrm{mg} / \mathrm{kg}$ ). For drain water and groundwater, transects 6 and 7 belong to the high arsenic group as 
shown in Fig. 5. For drain water, the mean arsenic value ranged from 20.39 to $22.40 \mu \mathrm{g} / \mathrm{L}$ and for groundwater it ranged from 10 to $22.35 \mu \mathrm{g} / \mathrm{L}$. This was the main industrial region and industries found here are mainly for chemicals, dyeing units, motor vehicle parts, and food. The motor vehicle industries use metallic arsenic in alloying with lead because lead batteries are strengthened by adding arsenic. It is also used in the processing of pigments, textiles, etc. Charar
Drain and Sattu Katla Drain also join Hudaira Drain in this section (Fig. 1). Sattu Katla is highly polluted because it comes from the Quaid-i-Azam industrial area in the township. Recent studies have also shown an increased level of arsenic [23, 24] in different areas of Pakistan. If this groundwater with high arsenic will be used continuously for irrigation, then the arsenic concentration in the soil will exceed the permissible limit.

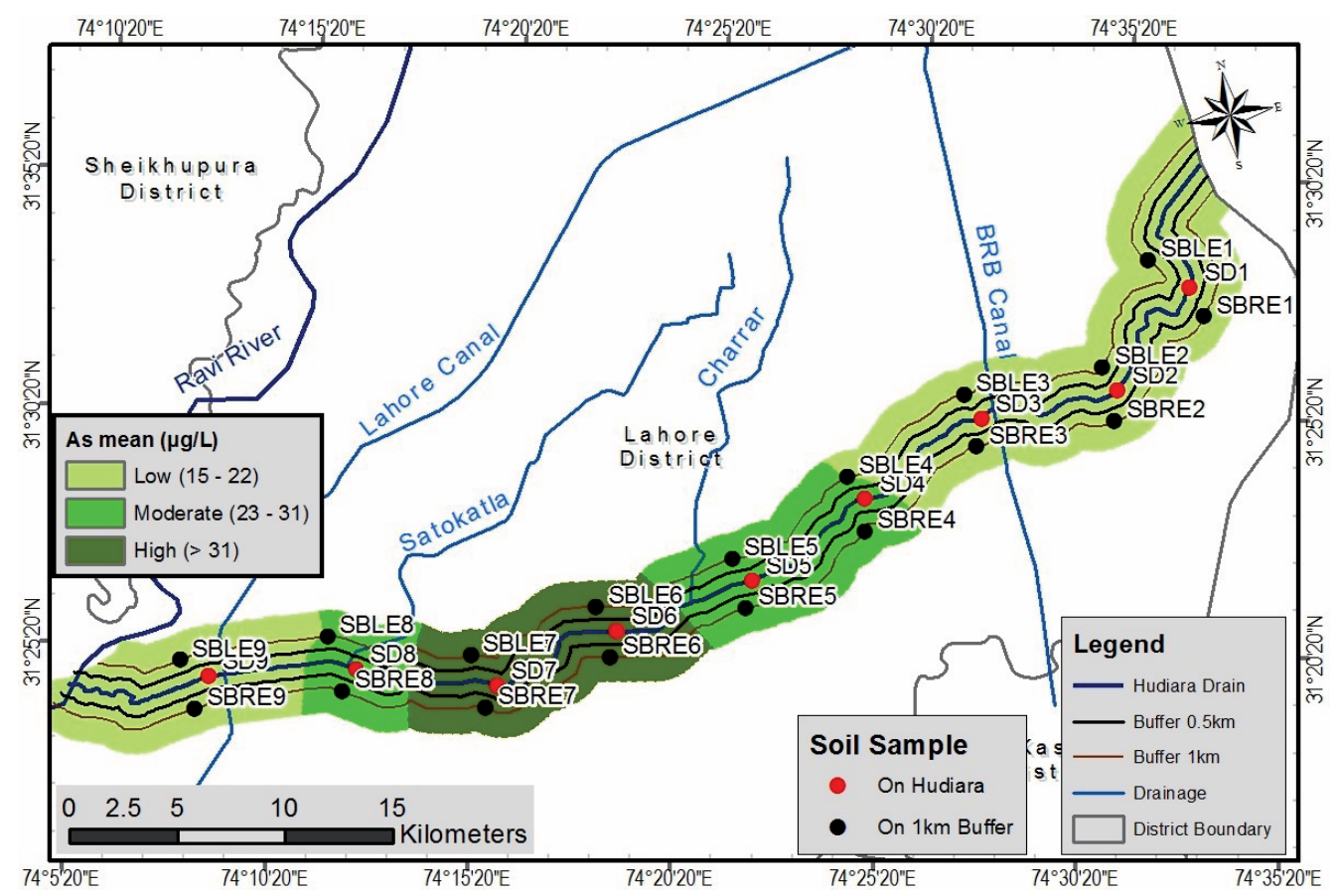

Fig. 4. Interpolation of mean arsenic value for soil samples.

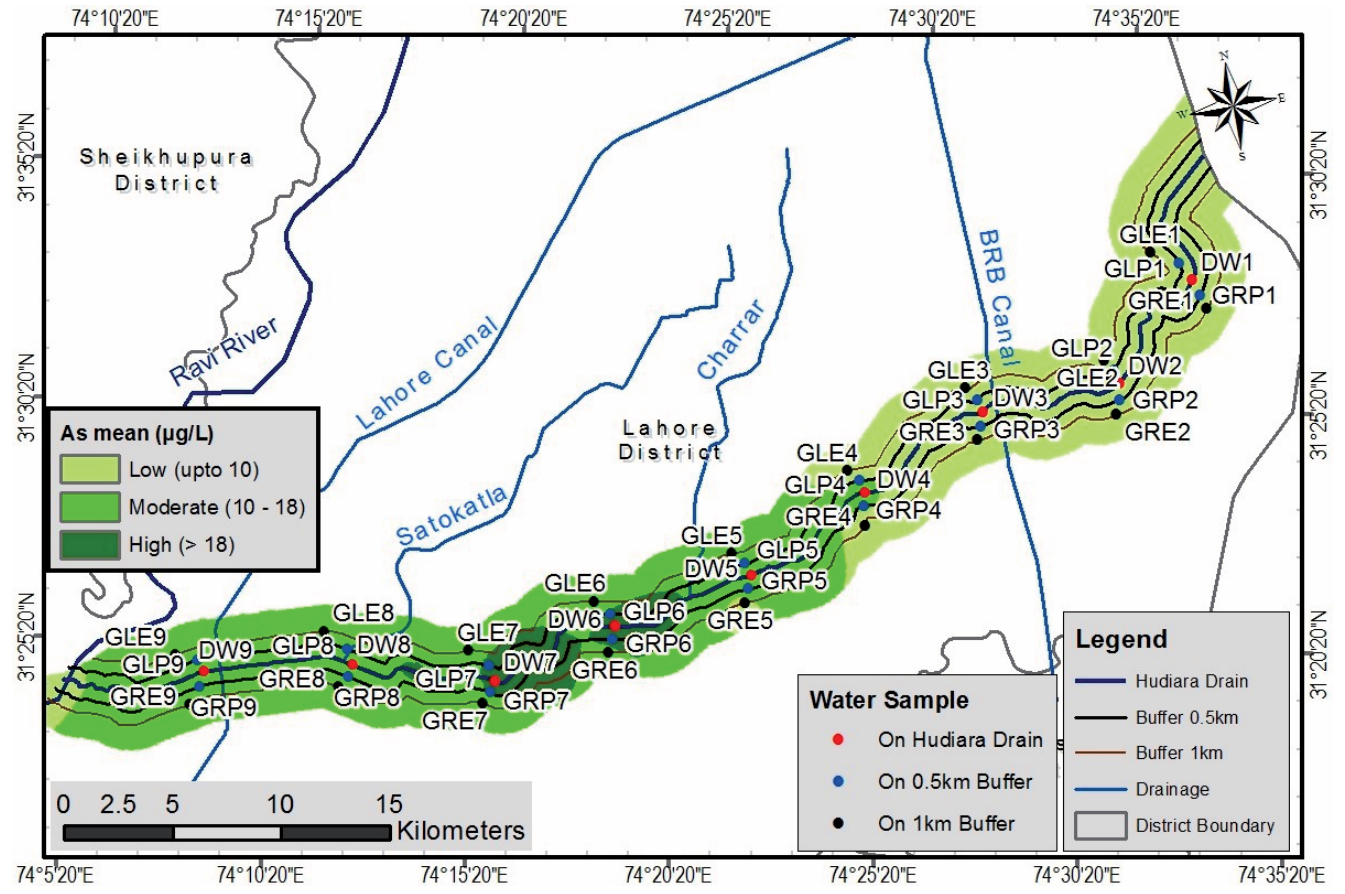

Fig. 5. Interpolation of mean arsenic value for drain water and groundwater samples. 
Statistically, Pearson's correlation was applied to drain water (surface water) and groundwater data (Fig. 6). All the $\mathrm{p}$ values were taken at $95 \%$ confidence level in the study. There is a very strong correlation of $87.7 \%(r=0.8774)$ between drain water (surface water) and groundwater with $\mathrm{p}$ value of 0.0001 , which is highly significant. There is a strong correlation of $74.8 \%$ $(\mathrm{r}=0.7489)$ between drain water (surface water) and soil samples on the extremes (one $\mathrm{km}$ buffer) with $\mathrm{p}$ value of 0.0001 , which is highly significant as shown in Fig. 7. Fig. 8 shows the correlation between soil samples on the drain and soil samples on the extremes (one $\mathrm{km}$ buffer). There is a strong correlation of $86.4 \%(\mathrm{r}=0.8645)$ between soil samples on the drain and soil samples on the extremes (one $\mathrm{km}$ buffer) with $\mathrm{p}$ value of 0.0001 , which is highly significant. Fig. 9 shows the box plot for mean arsenic values of sample sites. Keeping in view the values of arsenic in groundwater samples, the impact of arsenic on human beings was determined. It is considered that oral intake is the only source of exposure. Possible risk and threats were determined in view of the carcinogenic and non-carcinogenic effects of arsenic. Risks of lifetime cancer through oral intake of arsenic in groundwater samples were estimated by Equation 4. Evaluation of non-carcinogenic threats due to arseniclaced drinking water was determined by comparing the chronic daily intake of non-carcinogenic with oral reference doses of arsenic. It was observed that due to the high value of HQ, the possibility of threats of the non-carcinogenic due to arsenic poisoning in the area was high. Intake threat possibility is extensively used to identify relevant non-carcinogenic threats as compared to other possible routes of arsenic intake. In different sample sites, quantitative risks and hazards due to arsenic poisoning are shown in Table 4.

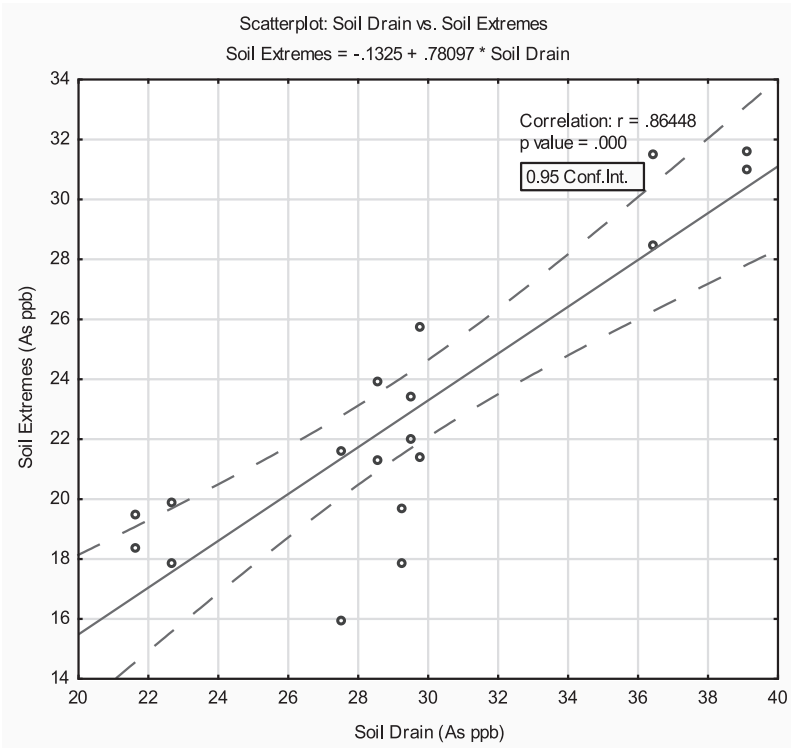

Fig. 8. Scatterplot between soil drain and soil extremes.

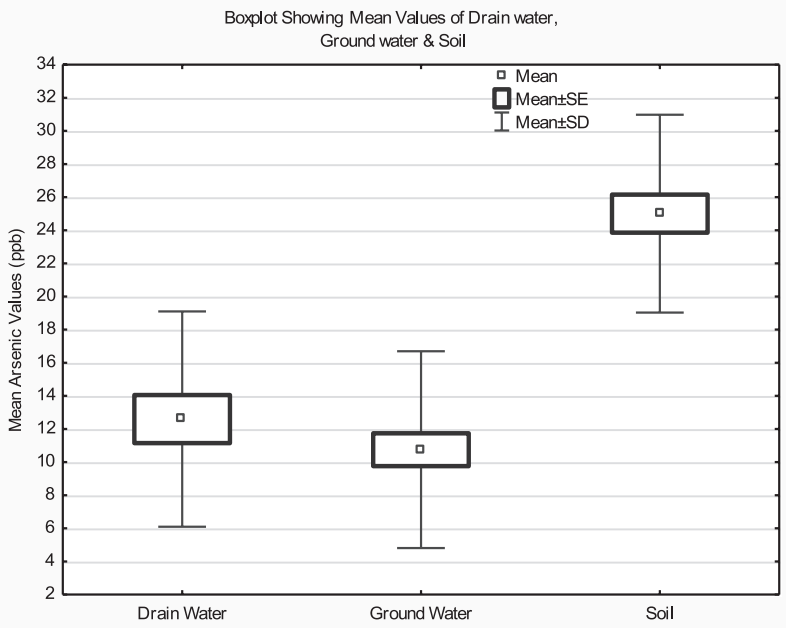

Fig. 9. Boxplot for mean arsenic of sample sites.
Fig. 7. Scatter plot between drain water and soil.
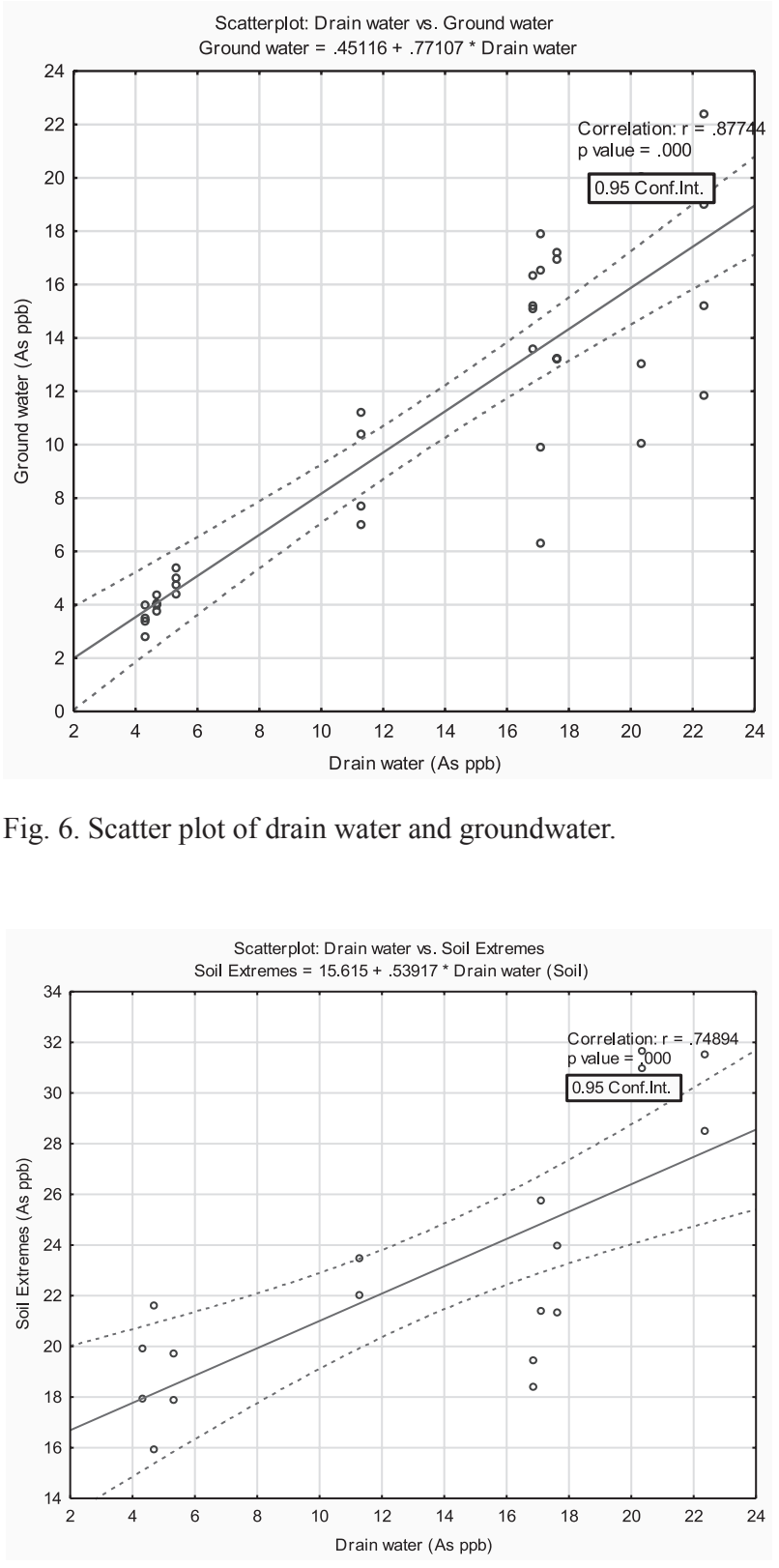

Fig. 6. Scatter plot of drain water and groundwater. 
Table 4. Arsenic concentrations and relevant risk and hazard levels in sample sites.

\begin{tabular}{|c|c|c|c|c|c|}
\hline Sites & $\begin{array}{l}\text { CDI (Adult) } \\
\text { (mg / kg/day) }\end{array}$ & $\begin{array}{l}\text { CDI (Child) } \\
\text { (mg/kg/day) }\end{array}$ & $\begin{array}{l}\text { Child Ingestion Hazard } \\
\text { Quotient(HQ) }\end{array}$ & $\begin{array}{c}\text { Adult Ingestion Hazard } \\
\text { Quotient }(\mathrm{HQ})\end{array}$ & ELCR \\
\hline GRP1 & $9.2 \mathrm{E}-05$ & $2.1 \mathrm{E}-4$ & 0.7 & 0.3 & $2.8 \mathrm{E}-05$ \\
\hline GRP2 & $1.2 \mathrm{E}-04$ & $2.8 \mathrm{E}-4$ & 0.9 & 0.4 & 3.6E-05 \\
\hline GRP3 & $1.5 \mathrm{E}-04$ & $3.4 \mathrm{E}-4$ & 1.1 & 0.5 & 4.4E-05 \\
\hline GRP4 & $3.1 \mathrm{E}-04$ & 7.1E-4 & 2.4 & 1.0 & 9.2E-05 \\
\hline GRP5 & 4.9E-04 & $1.1 \mathrm{E}-3$ & 3.8 & 1.6 & $1.5 \mathrm{E}-04$ \\
\hline GRP6 & $6.1 \mathrm{E}-04$ & $1.4 \mathrm{E}-3$ & 4.8 & 2.0 & $1.8 \mathrm{E}-04$ \\
\hline GRP7 & $5.5 \mathrm{E}-04$ & $1.3 \mathrm{E}-3$ & 4.3 & 1.8 & $1.6 \mathrm{E}-04$ \\
\hline GRP8 & 4.6E-04 & $1.1 \mathrm{E}-3$ & 3.6 & 1.5 & $1.4 \mathrm{E}-04$ \\
\hline GRP9 & 4.2E-04 & $9.7 \mathrm{E}-4$ & 3.2 & 1.4 & $1.3 \mathrm{E}-04$ \\
\hline GLP1 & $1.1 \mathrm{E}-04$ & $2.5 \mathrm{E}-4$ & 0.8 & 0.4 & $3.3 \mathrm{E}-05$ \\
\hline GLP2 & $1.1 \mathrm{E}-04$ & $2.5 \mathrm{E}-4$ & 0.8 & 0.4 & $3.9 \mathrm{E}-05$ \\
\hline GLP3 & $1.3 \mathrm{E}-04$ & $3.0 \mathrm{E}-4$ & 1.0 & 0.4 & $8.5 \mathrm{E}-05$ \\
\hline GLP4 & $2.8 \mathrm{E}-04$ & $6.6 \mathrm{E}-4$ & 2.2 & 0.9 & $1.4 \mathrm{E}-04$ \\
\hline GLP5 & $4.5 \mathrm{E}-04$ & $1.1 \mathrm{E}-3$ & 3.5 & 1.5 & $1.6 \mathrm{E}-04$ \\
\hline GLP6 & 5.2E-04 & $1.2 \mathrm{E}-3$ & 4.0 & 1.7 & $1.7 \mathrm{E}-04$ \\
\hline GLP7 & $5.5 \mathrm{E}-04$ & $1.3 \mathrm{E}-3$ & 4.3 & 1.8 & $1.4 \mathrm{E}-04$ \\
\hline GLP8 & 4.7E-04 & $1.1 \mathrm{E}-3$ & 3.7 & 1.6 & $1.3 \mathrm{E}-04$ \\
\hline GLP9 & $4.5 \mathrm{E}-04$ & $1.0 \mathrm{E}-3$ & 3.5 & 1.5 & $2.3 \mathrm{E}-05$ \\
\hline GRE1 & $7.5 \mathrm{E}-05$ & $1.8 \mathrm{E}-4$ & 0.6 & 0.3 & $3.3 \mathrm{E}-05$ \\
\hline GRE2 & $1.1 \mathrm{E}-04$ & $2.6 \mathrm{E}-4$ & 0.9 & 0.4 & 4.1E-05 \\
\hline GRE3 & $1.4 \mathrm{E}-04$ & $3.2 \mathrm{E}-4$ & 1.0 & 0.5 & 5.7E-05 \\
\hline GRE4 & $1.9 \mathrm{E}-04$ & 4.4E-4 & 1.5 & 0.6 & $5.2 \mathrm{E}-05$ \\
\hline GRE5 & $1.7 \mathrm{E}-04$ & $4.0 \mathrm{E}-4$ & 1.3 & 0.6 & $1.3 \mathrm{E}-04$ \\
\hline GRE6 & $4.2 \mathrm{E}-04$ & $9.7 \mathrm{E}-4$ & 3.2 & 1.4 & $8.3 \mathrm{E}-05$ \\
\hline GRE7 & $2.7 \mathrm{E}-04$ & $6.4 \mathrm{E}-4$ & 2.1 & 0.9 & $1.1 \mathrm{E}-04$ \\
\hline GRE8 & $3.6 \mathrm{E}-04$ & $8.4 \mathrm{E}-4$ & 2.8 & 1.2 & $1.1 \mathrm{E}-04$ \\
\hline GRE9 & $3.7 \mathrm{E}-04$ & $8.7 \mathrm{E}-4$ & 2.9 & 1.2 & $2.9 \mathrm{E}-05$ \\
\hline GLE1 & $9.5 \mathrm{E}-05$ & $2.2 \mathrm{E}-4$ & 0.7 & 0.3 & $3.1 \mathrm{E}-05$ \\
\hline GLE2 & $1.0 \mathrm{E}-04$ & $2.4 \mathrm{E}-4$ & 0.8 & 0.3 & $3.6 \mathrm{E}-05$ \\
\hline GLE3 & $1.1 \mathrm{E}-04$ & $2.8 \mathrm{E}-4$ & 0.9 & 0.4 & $6.3 \mathrm{E}-05$ \\
\hline GLE4 & $2.1 \mathrm{E}-04$ & 4.9E-4 & 1.6 & 0.7 & $8.1 \mathrm{E}-05$ \\
\hline GLE5 & $2.7 \mathrm{E}-04$ & $6.3 \mathrm{E}-4$ & 2.1 & 0.9 & $9.7 \mathrm{E}-05$ \\
\hline GLE6 & $3.2 \mathrm{E}-04$ & $7.5 \mathrm{E}-4$ & 2.5 & 1.1 & $1.1 \mathrm{E}-04$ \\
\hline GLE7 & $3.6 \mathrm{E}-04$ & $8.3 \mathrm{E}-4$ & 2.8 & 1.2 & $1.1 \mathrm{E}-04$ \\
\hline GLE8 & $3.6 \mathrm{E}-04$ & $8.4 \mathrm{E}-4$ & 2.8 & 1.2 & $1.2 \mathrm{E}-04$ \\
\hline GLE9 & $4.1 \mathrm{E}-04$ & $9.6 \mathrm{E}-04$ & 3.2 & 1.4 & $2.8 \mathrm{E}-05$ \\
\hline
\end{tabular}

$\mathrm{HQ}<1=$ Safe $\quad \mathrm{HQ}>1=$ Unsafe $\quad$ ELCR $1.0 \mathrm{E}-06$ to $1.0 \mathrm{E}-04=$ Acceptable. $\quad$ ELCR $>1.0 \mathrm{E}-04=$ High Risk Where

$\mathrm{GRP}=$ Groundwater samples on right side of drain at half $\mathrm{km}$

$\mathrm{GLP}=$ Groundwater samples on left side of drain at half $\mathrm{km}$

GRE $=$ Groundwater samples on right side of drain at one $\mathrm{km}$

$\mathrm{GLE}=$ Groundwater samples on left side of drain at one $\mathrm{km}$ 


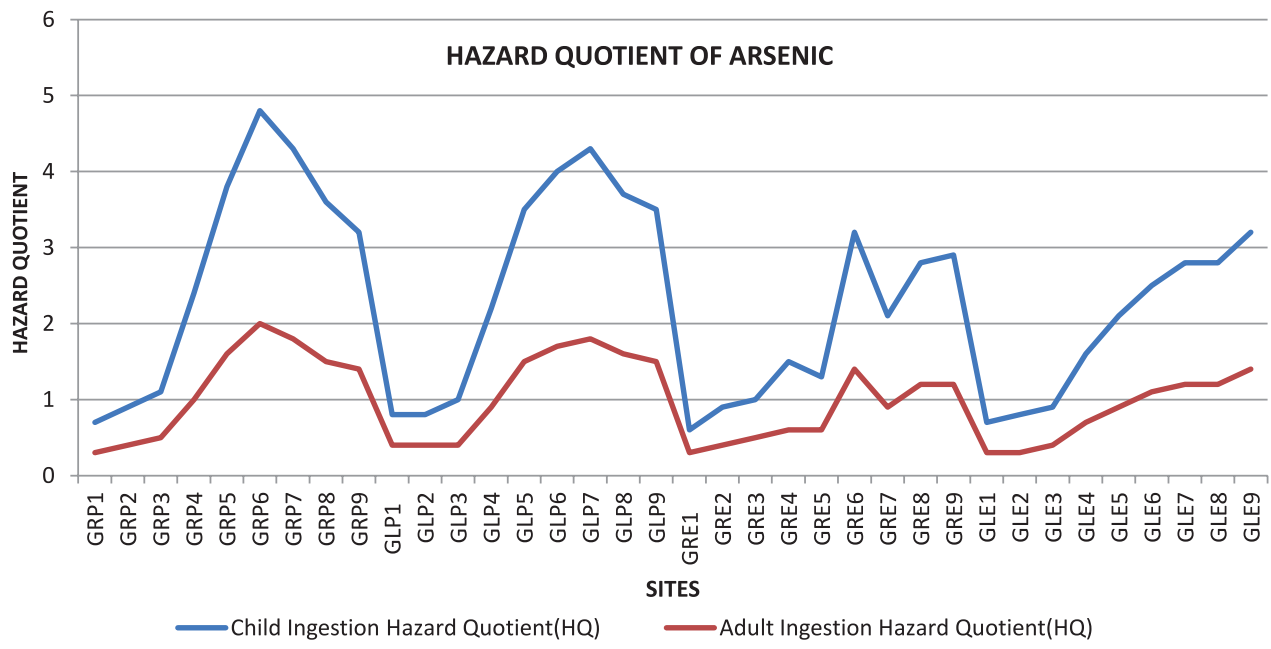

Fig. 10. Line graph for hazard quotient of arsenic for sample sites.

The highest and lowest arsenic concentrations were reported at GRP6 and GRE1, with $22.35 \mu \mathrm{g} / \mathrm{L}$ and $2.75 \mu \mathrm{g} / \mathrm{L}$, respectively. The highest value of $22.35 \mu \mathrm{g} / \mathrm{L}$ seems to be very high while comparing with the highest values of arsenic in groundwater in Xiangjiang watershed in south-central China, which is $21.2 \mu \mathrm{g} / \mathrm{L}$ [41]. The inorganic form of As is more dangerous than the organic one, whereas inorganic $\mathrm{As}(\mathrm{III})$ is nearly 60 times more dangerous than $\mathrm{As}(\mathrm{V})$ [42]. The continuous intake of groundwater with high As (V) for a long period would eventually cause hazards to human health because it is reduced to arsenite, which is more complicated to eliminate from supplies of drinking water than arsenate $[43,44]$.

The spatial distribution of age-adjusted ELCR and hazard levels among 36 sites of the study area are shown in Table 4, which shows that $50 \%$ of the adults have HQ value greater than 1 , meaning that they are unsafe and are more prone to non- carcinogenic threats due to arsenic. For child HQ $>1,75 \%$ of the children in the study area are more prone to the severity of non- carcinogenic threats due to arsenic in groundwater. Fig. 10 also shows the HQ levels for adults and children. The range of carcinogenic risks acceptable or tolerable by [45] was $1.0 \mathrm{E}-06$ to $1.0 \mathrm{E}-04$.

Values of the risk of cancer varied from highest $1.8 \mathrm{E}-04$ at GRP6 to2.3E-05 at GRE1. This study revealed that if only drinking water intake is considered, then even $44.4 \%$ of individuals have excess lifetime cancer risk $>10^{-4}$, showing high-risk. Hence, it is seen that nearly half of the individuals have a high risk of ELCR only through drinking water.

\section{Conclusion}

It is concluded from the present study that $52 \%$ of groundwater samples have arsenic value above the WHOrecommended limits. P-value indicates that there is a strong relationship between drain water, groundwater, and soil. The health risk assessment values $50 \%$ for $\mathrm{HQ}$ (ADULT) and $75 \%$ for HQ (CHILD) were found to be above unity, indicating significant risk via the ingestion route. In the samples of groundwater from the study area, the carcinogenic risk was found to be associated with the slightly elevated values of arsenic. Such drinking water sources have the potential to pose carcinogenic and noncarcinogenic effects on the local people of the study area. Therefore, the decision regarding substitution of current drinking water with safe and clean water must be taken as early as possible. This study can be used for future drinking water quality monitoring and planning in order to help save local people from the carcinogenic effects of arsenic.

\section{Acknowledgements}

The authors would like to thank Environmental Science Laboratory, Kinnaird College for Women, Lahore and Dr. Mahmood Ahmed Manager Operations, Renacon Pharma Ltd. for providing them testing facilities at their labs.

\section{Conflict of Interest}

The authors declare that there are no conflicts of interest.

\section{References}

1. SOBUKOLA O.P., DAIRO O.U. Modeling drying kinetics of fever leaves (Ocimumviride) in a convective hot air dryer. Niger. Food J. 25 (1) 145, 2007.

2. SYED J.H., MALIK R.N. Occurrence and source Identification of Organo chloride pesticidesin the surrounding surface soils of the Ittehad Chemical Indusries Kalashah Kaku, Pakistan, Environ. Earth Sci. 62, 1311, 2011. 
3. RASHID H., TAKEMURA J., FAROOQI A.M. Investigation of subsurface contamination due to Chromium from Tannery effluent in Kasur district of Pakistan, J. Environ. Sci. Eng. 1 (8A), 1007, 2012.

4. ENE A., BOSNEAGA A., GEORGESCU L. Determination of heavy metals in soils using XRF technique, Rom. J. Phys. 55 (7-8), 815, 2010.

5. RADWAN M.A., SALAMA A.K. Market basket survey for some heavy metals in Egyptian fruits and vegetables. Food Chem Toxicol. 44, 1273, 2006.

6. ISHAQ M., JAN F.A., KHAN M.A., IHSANULLAH I., AHMAD I., SHAKIRULLAH M. Effect of mercury and arsenic from industrial effluents on the drinking water and comparison of the water quality of polluted and nonpolluted areas: a case study of Peshawar and Lower Dir, Environ. Monit. Assess. 185 (2), 1483, 2013.

7. BAIG J.A., KAZI M.B., ARAIN M.B., AFRIDI H.I., KANDHRO G.A., SARFRAZ R.A., SHAH A.Q. Evaluation of arsenic and other physico-chemical parameters of surface and groundwater of Jamshoro, Pakistan, J. Hazard. Mater. 166 (2-3), 662, 2009.

8. FAROOQI A., MASUDA H., SIDDIQUI R., NASEEM M. Sources of arsenic and fluoride in highly contaminated soils causing groundwater contamination in Punjab, Pakistan, Archives of Environmental Contamination and Toxicology, 56 (4), 693, 2009.

9. PAKISTAN COUNCIL OF RESEARCH IN WATER RESOURCES (PCRWR) Ministry of Science and Technology, Islamabad, Pakistan, 2003.

10. NATIONAL ACADEMY OF SCIENCES/NATIONAL RESEARCH COUNCIL (NAS/NRC) Arsenic in drinking water, Washington. DC, 251, 1999.

11. BRAHMAN K.D., KAZI T.G., AFRIDI H.I. et al. Simultaneously evaluate the toxic levels of fluoride and arsenic species in underground water of Tharparkar and possible contaminant sources: a multivariate study, Ecotox. Environ. Safe. 89, 95, 2013.

12. AGENCY FOR TOXIC SUBSTANCES AND DISEASE REGISTRY (ATSDR) www.atsdr.cdc.gov/., 2009.

13. MALANA M.A., KHOSA M. A. Groundwater pollution with special focus on arsenic, Dera Ghazi Khan-Pakistan, J. Saudi Chem. Soc. 15 (1), 39, 2011.

14. TASKEEN A., I. NAEEM I., SIDDIQUE Z. Public health risk of Arsenic contamination in food at old Kahna, Lahore, Pakistan, Asian J. Chem. 21 (4), 2845, 2009.

15. LIU Y., ZHENH B., FU Q., MENG W., WANG Y. Risk assessment and management of arsenic in source water in China. J. Hazard. Mater. 170, 729, 2009.

16. MUHAMMAD S., SHAH T., KHAN S. Arsenic health risk assessment in drinking water and source apportionment using multivariate statistical techniques in Kohistan region, northern Pakistan, Food Chem. Toxicol. 48 (10), $2855,2010$.

17. MUKHERJEE A., SENGUPTA M.K., HOSSAIN M.A., AHMAD S., DAS B., NAYAK B., LODH D., RAHMAN M.M, CHAKRABORTI D. Arsenic contamination in groundwater: a global perspective with emphasis on the Asian scenario. J. Health Popul. Nutr. 24 (2), 142, 2006.

18. BARATI A.H., MALEKI A., ALASVAND M. Multi-trace elements level in drinking water and the prevalence of multi-chronic arsenical poisoning in residents in the west area of Iran. Sci. Total Environ. 408, 1523, 2012.
19. MALANA M.A., KHOSA M.A. Groundwater pollution with special focus on arsenic, Dera Ghazi Khan-Pakistan, J. Saudi Chem. Soc. 15 (1), 39, 2011.

20. MEHRDADI N., NABIBIDHENDI G.R., NASRABADI T., HOVEIDI H., AMJADI M., SHOJAEE M.A. Monitoring the Arsenic Concentration in Groundwater Resources, Case Study: Ghezelozan Water Basin, Kurdistan. Iran. Asian J. Chem, 21 (1), 446, 2009.

21. RAHMAN M.M., OWENS G., NAIDU R. Arsenic levels in rice grain and assessment of daily dietary intake of arsenic from rice in arsenic-contaminated regions of Bangladeshimplications to groundwater irrigation, Environ. Geochem. Hlth. 31 (1), 179, 2009.

22. TOOR I.A., TAHIR N.A. Study of arsenic concentration levels in Pakistani drinking water, Pol. J. Environ. Stud. 18 (5), 907, 2009.

23. FAROOQI A., MASUDA H., FIRDOUS N. Toxic fluoride and arsenic contaminated groundwater in the Lahore and Kasur district, Punjab, Pakistan and possible contaminant sources. Environ. Pollut. 145, 839, 2007.

24. BRAHMAN K.D., KAZI T.G., AFRIDI H.I., NASEEM S., ARAIN S.S., ULLAH N. Evaluation of high levels of fluoride, arsenic species and other physicochemical parameters in underground water of two sub districts of Tharparkar, Pakistan: a multivariate study, Water Res. 47 (3), 1005, 2013.

25. WORLD HEALTH ORGANIZATION (WHO) Guidelines for drinking water quality, World Health Organization.4th Ed. Geneva, Switzerland, 2011

26. HUSAIN V., NASEEM S., KHAN A., BHATTACHARYA P., ARAIN G.M. Natural arsenic in groundwater of Indus delta in the province of Sindh, Pakistan. In: Noller BN. Naidu R. Bundschuh J. Bhattacharya P. (Eds.). Understanding the Geological and Medical Interference of Arsenic-Ng. Taylor \& Francis Group, London, 2012.

27. NASEEM S. Groundwater quality assessment for determining geogenic pollution, contamination and health effects in Thatta-Hyderabad region, Sindh, Unpublished Ph.D. thesis, Department of Geology, University of Karachi, 2012.

28. MAJIDANO S.A., ARAIN G.M., BAJAJ D.R., IQBAL P., KHUHAWAR M.Y. Assessment of groundwater quality with focus on arsenic contents and consequences, Case study of Tando Allahyar District in Sindh Province. Int. J. Environ. Eng. 1, 91, 2010.

29. HUSAIN V. Sindh Education Reform Program (SERP). Drinking Water Quality component. A study for World Bank. file report, 2009.

30. ARAIN G.M., ASLAM M., MAJIDANO S.A. Arsenic contamination of underground water in district matiari and Khairpur. J. Chem. Soc. Pak. 25 (5), 2007.

31. ASLAM H., KHAN M., KHAN H.N. (2003). Hudaira Drain-A Case of Trans-Boundary Water Pollution Between India and Pakistan. Pak. J.Biol. Sci. 6 (2), 167, 2003.

32. AFZAL S., FAROOQ M., KHAN M.H.A., KHAN M.I., ALI K. Nitrate, fecal colliform and pesticides in shallow groundwater of Raiwind, Lahore, Pakistan. Proc. $67^{\text {th }}$ Annual Session Symposium on Environment Protection and Resource Conservation by Pakistan Engineering Congress XXV: 14, 1998.

33. KANWAL S., GABRIEL H.F., MAHMOOD K., ALI R., HAIDAR A., TEHSEEN T. Lahore's groundwater depletion-A review of the aquifer susceptibility to degradation and its consequences. University of 
Engineering and Technology Taxila. Tech. J. 20 (1), 26, 2015.

34. ENVIRONMENTAL PROTECTION DEPARTMENT (EPD) PUNJAB AND WORLD-WIDE FUND (WWF) United Nations Development Programme (UNDP) project, Water quality monitoring of Hudaira drain, Lahore, Pakistan, 2001

35. IPD. Estimate for cleaning of Hudaira Nullah Lahore. Irrigation and Power Department (IPD) Punjab, Lahore, Pakistan, 2002

36. AFZAL S., AHMAD I., YOUNAS M., ZAHID M.D., KHAN M.H.A., IJAZ A., ALI K. tudy of water quality of Hudaira Drain, India-Pakistan. Environ. Geol. 26, 87, 2000.

37. YASAR A., AHMAD N., CHAUDHRY M.N., SARWAR M. The effect of industrial effluent stream on the ground water. Proc. International Conference on Environmentally Sustainable Development, COMSATS. Pakistan 2, 1005, 2005.

38. YAMIN M.T., AHMAD N. Influence of Hudaira drain water irrigation on trace elements load in soil and uptake by vegetables. J. Appl. Sci. Environ. Manage. 11, 169, 2007.

39. WWF. Hudaira drain Pollution Control: Prefeasibility study, Cleaner Production Institute, Lahore, 2007.

40. APHA/AWWA/WEF Standard Methods for the Examination of Water and Wastewater. American Public Health Association. AMERICAN Water Works
Association, Water Environment Federation. Washington D.C. USA, 2006.

41. CHAI L., WANG Z., WANG Y., YANG Z., WANG $\mathrm{H}$., WU X. Ingestion risks of metals in groundwater based on TIN model and dose-response assessment - A case study in the Xiangjiang watershed, central-south China. Sci. Total Environ. 408, 3118, 2010.

42. AKHTER G., AHMAD Z., IQBAL J., SHAHEEN N., SHAH M.H. Physicochemical characterization of groundwater in urban areas of Lahore, Pakistan, with special reference to arsenic, J. Chem. Soc. Pak. 32 (3), 306, 2010.

43. MUHAMMAD S. SHAH M.T., KHAN S. Arsenic health risk assessment in drinking water and source apportionment using multivariate statistical techniques in Kohistan region, northern Pakistan, Food Chem Toxicol. 48 (10), 2855, 2010.

44. NAFEES A.A., KAZI A., FATIMI Z., IRFAN M., ALI A., KAYAMA F. Lung function decrement with arsenic exposure to drinking groundwater along River Indus, Environ. Geochem. Hlth. 33 (2), 203, 2011.

45. USEPA. Risk-Based Concentration Table. United States Environmental Protection Agency, 2010. Available at: $\quad$ http://www.epa.gov/reg3hwmd/risk/human/index. htm.2010.

46. RISK ASSESSMENT INFORMATION System (RAIS). 2009. (http://www.rais.ornl.gov/) 